\title{
PROFIL KEMAMPUAN BERPIKIR KRITIS SISWA SD DI KECAMATAN BULAK
}

\author{
${ }^{1)}$ Lydia Lia Prayitno ${ }^{2)}$ Ida Sulistyawati ${ }^{3)}$ Imas Srinana Wardani \\ ${ }^{1)}$ lydia.liaprayitno5@gmail.com ${ }^{2)}$ Ida_pgsd@yahoo.com \\ ${ }^{3)}$ imassrinanawardani@ rocketmail.com \\ Universitas PGRI Adi Buana Surabaya
}

\begin{abstract}
Abstrak
Kemampuan berpikir kritis ada pada semua orang, tetapi tidak muncul sendiri, perlu usaha untuk mengembangkannya, salah satunya adalah dengan kemampuan dasar guru, yaitu keterampilan bertanya, hal ini diperlihatkan oleh siswa SD kelas I di wilayah kecamatan Bulak yaitu SDN Sukolilo 250, SDN Kedung Cowek I No. 253, SDN Kedung Cowek II, SDN Komplek Kenjeran II/506, dan SDN 248.

Melalui penelitian deskriptif kualitatif pada siswa SD kelas I di wilayah kecamatan Bulak Aspek-aspek berpikir kritis pada siswa terlihat dan dapat diamati, yaitu aspek mengamati dan menarik kesimpulan, membandingkan dua objek yang berbeda, kemampuan bertanya dan mengemukakan pendapat, mendiskusikan dan menganalisa cerita dan kerjasama dalam permainan. Ke 5 aspek tersebut terlihat pada siswa.
\end{abstract}

Kata kunci : berpikir kritis, siswa $S D$

\section{Pendahuluan}

\section{A. Berpikir Kritis}

Berpikir kritis adalah sikap yang diasah dan dipelajari. Aspek yang penting yang mempengaruhi proses berpikir kritis misalnya seperti disiplin. Seseorang yang berpikir kritis akan dapat menjawab permasalahan-permasalahan yang penting dengan baik. Berpikir kritis merupakan suatu keterampilan yang menggunakan pengetahuan dan intelegensi untuk mendapatkan objektivitas dan pandangan yang dapat diterima secara akal. Salah satu tujuan utama pembelajaran ialah meningkatkan kemampuan siswa berpikir kritis, agar dapat mengambil keputusan rasional tentang apa yang harus dilakukan atau apa yang harus diyakini. Berpikir kritis merupakan potensi yang dimiliki oleh setiap orang, dapat di ukur, dilatih, dan dikembangkan Lambertus (2009).

$$
\text { Pembelajaran berpikir }
$$

kritis memerlukan latihan, siswa diberi banyak dilema, argument logis dan tidak logis (Halpern, 1995 dalam Slavin, 2011). Pengajaran berpikiran kritis yang efektif bergantung pada penentuan suasana ruang kelas yang mendorong penerimaan sudut 
pandang yang berlainan dan diskusi bebas. Kemampuan pemikiran kritis paling baik dipelajari melalui pengaitan dengan topik yang tidak asing bagi siswa.

Menurut Hassoubah (2007) cara meningkatkan kemampuan berpikir kritis yaitu; membaca dengan kritis, meningkatkan daya analisis, mengembangkan kemampuan observasi/mengamati, meningkatkan rasa ingin tahu, kemampuan bertanya dan refleksi, metakognisi, mengamati model dalam berpikir kritis, dan diskusi yang kaya.

Kemampuan berpikir kritis ada pada semua orang, menurut Bower dalam Takwin (2008) menjelaskan bahwa bayi dalam "tahap infansi" sudah dapat berpikir logis. Dengan begitu anak usia Sekolah Dasar (SD) sudah dapat dirangsang untuk berpikir kritis. Hal ini senada dengan Djaali (2008) antara umur 7 tahun s.d. 12 tahun, fungsi ingatan, imajinasi dan pikiran mulai berkembang, anak mulai berpikir kritis. Menurut Piaget (dalam Suparno, 2001) tahap operasi konkret (concrete operations) dicirikan dengan perkembangan system pemikiran yang didasarkan pada aturan-aturan tertentu yang logis. Oleh karena itu dapat dikatakan siswa kelas awal telah mengembangkan system pemikiran logis yang dapat diterapkan dalam memecahkan persoalan-persoalan konkret yang dihadapi.
Menumbuhkan keterampilan berpikir kritis pada siswa SD dapat dengan menggunakan beberapa metode atau strategi yang menuntut siswa dapat secara aktif mengembangkan keterampilan berpikir kritis. Cara berpikir siswa masih terbatas karena masih berdasarkan sesuatu yang konkrit, sehingga siswa masih mengalami kesulitan untuk memecahkan persoalan yang mempunyai banyak variable. Keterampilan berpikir kritis siswa SD kelas awal ditumbuhkan dengan proses bertanya dan menggunakan kurikulum 2013. Untuk siswa SD kelas I karena belum lancar membaca tulisan akan diganti dengan membaca gambar.

\section{B. Karakteristik Siswa SD Kelas Awal}

Siswa SD berada pada tahap operasi konkrit. Menurut Piaget (dalam Suparno, 2001) tahap operasi konkret (concrete operations) dicirikan dengan perkembangan system pemikiran yang didasarkan pada aturan-aturan tertentu yang logis. Oleh karena itu dapat dikatakan siswa kelas awal telah mengembangkan system pemikiran logis yang dapat diterapkan dalam memecahkan persoalan-persoalan konkret yang dihadapi. Cara berpikir siswa masih terbatas karena masih berdasarkan sesuatu yang konkrit, sehingga siswa masih mengalami kesulitan untuk memecahkan persoalan yang mempunyai banyak variable.

Tingkatan perkembangan intelektual siswa sekolah dasar pada 
usia (4-7 tahun) berada pada tahap berpikir intuitif ditandai oleh berpikir pralogis yaitu antara operasional konkret dengan prakonseptual. Pada tahap ini perkembangan ingatan siswa didik sudah mulai mantap, tetapi kemampuan berpikir deduktif dan induktif masih lemah/belum mantap.

Belajar berpikir kritis mempunyai arti bahwa siswa belajar bagaimana bertanya, kapan bertanya, dan apa metode penalaran yang dipakai. Untuk menumbuhkan kemampuan berpikir kritis siswa, sebaiknya dalam proses pembelajaran guru menggunakan metode pembelajaran yang mengajak siswa untuk berpikir, merangsang untuk bertanya dan mencari fakta dalam rangka menyelesaikan masalah atau tema. Dalam proses pembelajaran sebaiknya suasana kelas harus kondusif. Kegiatan kelas harus mengacu pada aktifitas siswa misalnya melalui diskusi kelas, dan penelitian sederhana.

\section{Metode Penelitian}

Penelitian ini adalah penelitian deskriptif kualitatif. Subjeknya adalah siswa SD kelas 1 di SD di wilayah kecamatan Bulak dengan Instrumen utama adalah peneliti sendiri. dengan langkahlangkah: (1) menelaah seluruh data yang tersedia dari berbagai sumber, yaitu dari hasil pemecahan masalah tertulis, wawancara, dan pengamatan yang sudah dituliskan dalam catatan lapangan, melakukan reduksi data, (3) menyusun dalam satuan- satuan yang selanjutnya dikategorisasikan (4) mengadakan pemeriksaan keabsahan data, (5) analisis hal-hal yang menarik, dan (6) penafsiran data/kesimpulan.

\section{Pembahasan}

Data yang sudah diperoleh dianalisis secara kualitatif. Analisis data dalam penelitian ini meliputi analisis terhadap proses pembelajaran siswa dan dipadukan dengan hasil observasi pada waktu pembelajaran dan wawancara dengan guru. Hasil wawancara di sekolah, di wilayah kecamatan Bulak yaitu SDN Sukolilo 250, SDN Kedung Cowek I No. 253, SDN Kedung Cowek II, SDN Komplek Kenjeran II/506, dan SDN 248 menyatakan bahwa kurikulum yang digunakan adalah kurikulum 2013, dan pada proses pembelajaran masih banyak siswa yang sulit untuk bertanya ataupun menjawab dikarenakan malu dan masih takut untuk menjawab. Pada proses pembelajaran yang kami lakukan, terlihat siswa aktif dalam pembelajaran. Hal-hal yang kami temukan dalam proses pembelajaran yang kami lakukan adalah : 


\section{A. Aspek-aspek yang ditemukan dari hasil penelitian dalam proses pembelajaran yang mendukung kemampuan berpikir kritis.}

\begin{tabular}{|c|c|c|}
\hline No & Aspek & Pencapaian \\
\hline 1 & Nilai-nilai agama dan moral & $\begin{array}{l}\text { 1. Mengenal agama yang dianut } \\
\text { 2. Menghormati agama orang lain } \\
\text { 3. Membedakan perilaku baik dan buruk } \\
\text { 4. Memahami perilaku utama (jujur, } \\
\text { penolong, sopan, hormat, dsb.) }\end{array}$ \\
\hline \multirow[t]{2}{*}{2} & $\begin{array}{l}\text { Fisik } \\
\text { a. Motorik Kasar }\end{array}$ & $\begin{array}{l}\text { 1. Melakukan koordinasi gerakan kaki- } \\
\text { tangan-kepala dalam menirukan perintah } \\
\text { tepukan semangat } \\
\text { 2. Terampil menggunakan tangan kanan } \\
\text { dan kiri } \\
\text { 3. Melakukan kegiatan kebersihan diri( } \\
\text { mengurus dirinya sendiri tanpa bantuan) }\end{array}$ \\
\hline & b. Motorik Halus & $\begin{array}{l}\text { 1. Menggunakan alat tulis dengan benar } \\
\text { 2. Menggambar - menulis dengan rapi } \\
\text { 3. Menempel gambar dengan tepat }\end{array}$ \\
\hline \multirow[t]{2}{*}{3} & $\begin{array}{l}\text { Kognitif } \\
\text { a. Pengetahuan umum dan } \\
\text { sains }\end{array}$ & 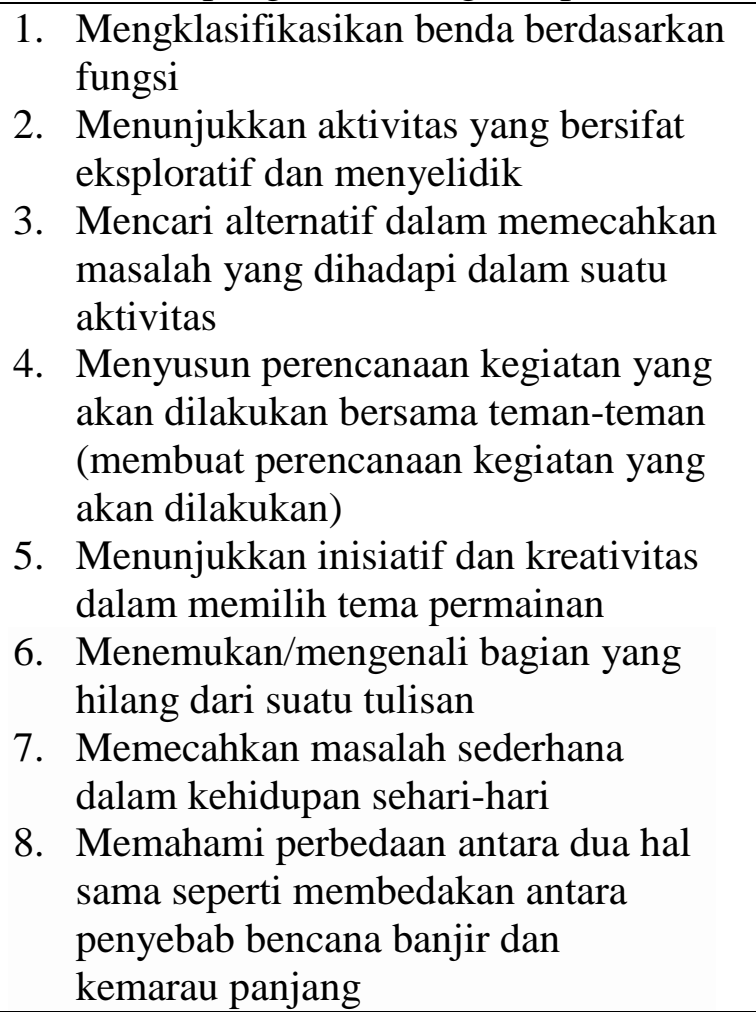 \\
\hline & $\begin{array}{l}\text { b. Mengenal Ukuran, } \\
\text { Bentuk, warna, dan Pola }\end{array}$ & $\begin{array}{l}\text { 1. Memahami konsep ukuran (besar - } \\
\text { kecil, panjang - pendek); } \\
\text { 2. Mulai mengikuti pola tepuk tangan; }\end{array}$ \\
\hline 4 & $\begin{array}{l}\text { Bahasa } \\
\text { a. Menerima Bahasa }\end{array}$ & $\begin{array}{l}\text { 1. Memahami cerita } \\
\text { 2. Memahami perintah sederhana, } \\
\text { seperti menunjuk tangan terlebih }\end{array}$ \\
\hline
\end{tabular}




\begin{tabular}{|c|c|c|}
\hline & & $\begin{array}{l}\text { dahulu sebelum menjawab } \\
\text { pertanyaan ataupun bertanya } \\
\text { 3. Mulai memahami dua perintah yang } \\
\text { diberikan bersamaan } \\
\text { 4. Memahami aturan dalam suatu } \\
\text { permainan }\end{array}$ \\
\hline & b. Mengungkapkan Bahasa & $\begin{array}{l}\text { 1. Menjawab pertanyaan yang lebih } \\
\text { kompleks (menjawab pertanyaan } \\
\text { tentang keterangan/informasi, } \\
\text { menggunakan dan dapat menjawab } \\
\text { pertanyaan apa, mengapa, dimana, } \\
\text { berapa, bagaimana, dsb) } \\
\text { 2. Menyebutkan kelompok gambar yang } \\
\text { memiliki fungsi yang sama } \\
\text { (menyebutkan berbagai gambar } \\
\text { tertentu, mengelompokkan macam- } \\
\text { macam gambar yang mempunyai } \\
\text { klasifikasi yang sama) } \\
\text { 3. Berkomunikasi secara lisan, memiliki } \\
\text { perbendaharaan kata, serta mengenal } \\
\text { symbol-simbol untuk persiapan } \\
\text { membaca, dan menulis. } \\
\text { 4. Menyusun kalimat sederhana dalam } \\
\text { struktur lengkap } \\
\text { 5. Memiliki lebih banyak kata-kata } \\
\text { untuk mengekspresikan ide pada } \\
\text { orang lain. } \\
\text { 6. Melanjutkan sebagian cerita/dongeng } \\
\text { yang telah diperdengarkan }\end{array}$ \\
\hline 5 & $\begin{array}{l}\text { Mampu mengendalikan } \\
\text { emosi }\end{array}$ & $\begin{array}{l}\text { 1. Bersikap kooperatif dengan teman } \\
\text { 2. Menunjukkan sikap toleran } \\
\text { 3. Mulai menunjukkan sikap toleran } \\
\text { sehingga dapat bekerja dalam } \\
\text { kelompok; } \\
\text { 4. Mengenal tata krama dan sopan } \\
\text { santun sesuai dengan nilai sosial } \\
\text { budaya setempat } \\
\text { 5. Memahami peraturan dan disiplin } \\
\text { 6. Menunjukkan rasa empati } \\
\text { 7. Memiliki sikap gigih (tidak mudah } \\
\text { menyerah) } \\
\text { 8. Bangga terhadap hasil karya sendiri } \\
\text { 9. Menghargai keunggulan orang lain } \\
\text { 10. Bereaksi terhadap hal-hal yang } \\
\text { dianggap tidak benar } \\
\text { 11. Mulai menunjukkan ekspresi me- }\end{array}$ \\
\hline
\end{tabular}


nyesal ketika melakukan kesalahan.

\section{B. Pembahasan Hasil Analisis profil Berpikir Kritis}

Aspek-aspek yang ditemukan dalam proses pembelajaran digunakan sebagai pengukuran akurasi dan prestasi berpikir kritis, yaitu :

\section{Mengamati dan menarik kesimpulan}

Pada aspek mengamati dan menarik kesimpulan dapat kita lihat pada aspek no 3, yaitu kognitif (pengetahuan umum dan sains) pencapaiannya terihat pada no 1 sampai dengan 6, yaitu:

1. Mengklasifikasikan benda berdasarkan fungsi

2. Menunjukkan aktivitas yang bersifat eksploratif dan menyelidik

3. Mencari alternatif dalam memecahkan masalah yang dihadapi dalam suatu aktivitas

4. Menyusun perencanaan kegiatan yang akan dilakukan bersama temanteman (membuat perencanaan kegiatan yang akan dilakukan)

5. Menunjukkan inisiatif dan kreativitas dalam memilih tema permainan

6. Menemukan/mengenali bagian yang hilang dari suatu tulisan

7. Memecahkan masalah sederhana dalam kehidupan sehari-hari
8. Memahami perbedaan

antara dua hal sama

seperti membedakan

antara penyebab bencana

banjir dan kemarau

panjang

Terdapat juga pada aspek no 4, yaitu bahasa, kategori a. Menerima bahasa dan mengungkapkan bahasa. Ketika siswa melihat 2 gambar yang dipasang di papan, guru menanyakan kepada siswa gambar apakah yang ada di papan, Terlihat siswa peka/tanggap terhadap lingkungan, mereka mengoptimalkan pemakaian indera, kemudian mengungkapkan secara verbal komentar yang ada di dalam pikiran, siswa dapat menjawab pertanyaan guru, dari mengamati gambar tersebut siswa dapat menjawab bahwa gambar tersebut adalah gambar hujan deras dan banjir, dan gambar ke dua adalah gambar sawah yang kering. Bahkan ada yang bertanya, bu kenapa pak taninya duduk di sawah, apa sedang sedih ya. Mengapa siswa dapat menjawab pertanyaan guru, dikarenakan kecenderungan belajar anak usia sekolah dasar memiliki tiga ciri yaitu konkret, integratif, dan hierarkis (majid, 2014). Konkret di sini diberikan gambar yang bisa dilihat, kemudian peristiwanya 


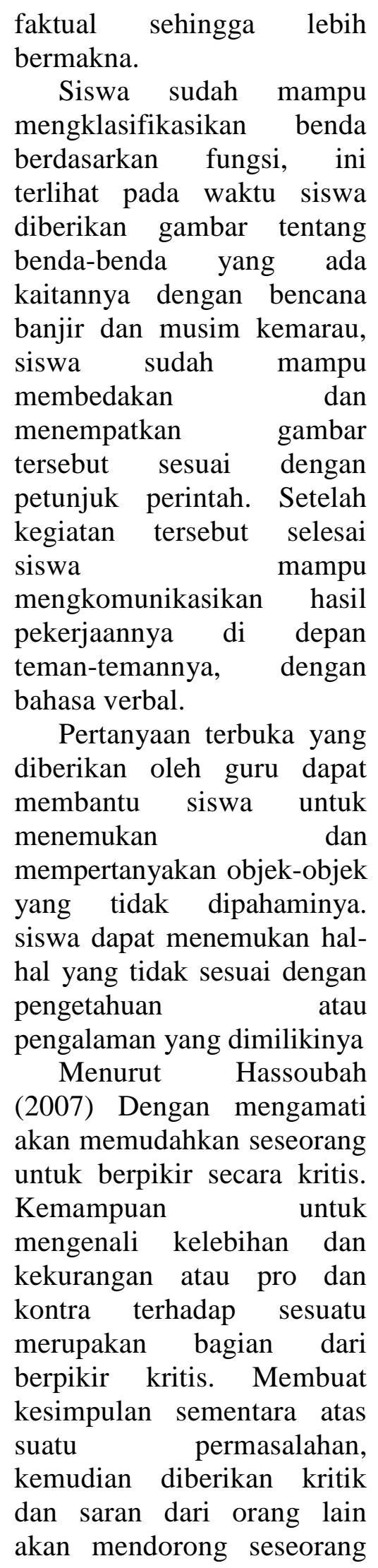

untuk memikirkan

alternative

2. Membandingkan dua objek yang berbeda

Terdapat pada aspek no 3, yaitu kognitif baik kategori a. Pengetahuan umum dan sains, maupun kategori b. Konsep bentuk, warna, ukuran dan pola pada waktu membandingkan dua objek yang berbeda, anak belajar menganalisa dan mengkategorikan persamaan maupun perbedaan dari objek yang diamati, ini terlihat pada waktu mereka diperlihatkan musibah banjir dan kemarau panjang, mereka dapat membedakan persamaan dan perbedaannya. menurut L.M. Sartolli, (1989) dalam Zaleha, ukuran dan kriteria seseorang dikatakan berpikir kritis Menghadapi tantangan demi tantangan dengan alasan-alasan, memberikan contoh-contoh dan argumen yang berbeda dari yang sudah ada, mencari dan memaparkan hubungan antara masalah atau pengalaman lain yang relevan

3. Kemampuan bertanya dan mengemukakan pendapat

Terdapat juga pada aspek no 4, yaitu bahasa, kategori a. Menerima bahasa dan mengungkapkan bahasa. Pertanyaan yang bermutu tidak mempunyai jawaban khusus, artinya tidak ada jawaban yang benar atau 
salah atau tidak hanya ada satu jawaban yang benar. Siswa dituntut untuk mencari jawaban sehingga menjadikan mereka banyak berpikir. Siswa diberi pertanyaan dan diberi kesempatan bertanya, serta diberi waktu yang cukup untuk mencari jawaban dari pertanyaan-pertanyaan

tersebut. ciri-ciri berpikir kritis menurut Ennis dalam Mardiana (2007:61) adalah: Mencari pertanyaan yang jelas dari setiap pertanyaan, mencari alasan, berusaha mengtahui informasi dengan baik.

\section{Mendiskusikan menganalisa cerita}

dan

Terdapat pada aspek no. 4, yaitu bahasa. kategori mengungkapkan b. Mengungkapkan bahasa Ini terlihat pada waktu siswa diminta untuk menceritakan kembali cerita yang sudah siswa dengar atau pada waktu guru membacakan dengan bahasa anak. Kemudian siswa ditanya pendapatnya mengenai isi cerita, karakter dan situasinya dan siswa mampu menghubungkan cerita dengan kejadian dalam kehidupan nyata. Mengapa terjadi banjir? Bolehkah kita membuang sampah sembarangan? Mengapa?

Untuk mengembangkan kemampuan berpikir kritis, memberikan pendapat dan mendengarkan pendapat orang lain adalah penting. Melibatkan diri dalam diskusi dapat mengembangkan

kemampuan berpikir kritis. Dalam diskusi ada pertukaran pendapat, berani menanggung resiko, kejutan, spontanitas serta adanya perbedaan pendapat dan tantangan sehingga bisa mengevaluasi serta mempertimbangkan pendapat tersebut yang pada akhirnya mencari pendapat lain atau menggabungkan antara satu pendapat dengan pendapat lain.

\section{Kerjasama dalam} permainan

Dapat kita lihat pada aspek no1, yaitu nilai-nilai agama dan permainan, aspek no 2, yaitu tentang fisik baik motorik kasar maupun motorik halus, dan aspek no. 5, yaitu mampu mengendalikan emosi Pada saat siswa diskusi, guru memberi kesempatan pada siswa untuk bekerjasama dengan teman-temannya, kemudian guru memberikan stimulus pada siswa agar berani mengungkapkan gagasan dan ide, serta mengeksplorasi kreativitas siswa. Ini terlihat pada waktu siswa dibuat kelompok dan diberikan gambar, dan menempelkannya di depan, kemudian siswa mempresentasikannya di depan, kemudian guru 
meminta kelompok lain untuk memberikan penilaian, agar siswa belajar mempertahankan pendapatnya dengan cara yangbaik.

Kemampuan berpikir kritis dapat membantu siswa membuat keputusan yang tepat berdasarkan usaha yang cermat, sistematis, logis dan mempertimbangkan berbagai sudut pandang. Dengan berpikir kritis, siswa terbiasa mempunyai sifat, sikap, nilai dan karakter yang baik. Mendidik anak berpikir kritis akan membantu anak untuk secara aktif membangun pertahanan diri terhadap serangan informasi di sekelilingnya.

\section{Kesimpulan}

Berdasarkan hasil analisis data dan diskusi hasil penelitian dapat disimpulkan, pada siswa SD kelas I di wilayah kecamatan Bulak yaitu, SDN Sukolilo 250, SDN Kedung Cowek I No. 253, SDN Kedung Cowek II, SDN Komplek Kenjeran II/506, dan SDN Kenjeran 248 dengan teknik bertanya terlihat keterampilan berpikir kritis siswa. Hal ini terlihat dari aspek-aspek untuk mengukur berpikir kritis siswa dalam pembelajaran, yaitu: 1) aspek Mengamati dan menarik kesimpulan, 2) Membandingkan dua objek yang berbeda, 3) Kemampuan bertanya dan mengemukakan pendapat, 4) Mendiskusikan dan menganalisa cerita, 5) Kerjasama dalam permainan. Ke lima aspek tersebut dapat diamati pada siswa SD kelas satu di 5 sekolah wilayah kecamatan Bulak. Artinya adalah bahwa kemampuan berpikir kritis ada pada semua orang, tetapi tidak akan muncul dengan sendirinya, perlu usaha untuk mengembangkan dalam proses pembelajaran, salah satunya adalah dengan kemampuan dasar guru, yaitu keterampilan bertanya.

\section{Daftar Pustaka}

Djaali, 2008. Psikologi Pendidikan. Jakarta: Bumi Aksara

Hassoubah, Zaleha Izhab. 2007. Mengasah Pikiran Kreatif dan Kritis. Bandung: Nuansa

Lambertus. (2009). Pentingnya Melatih Keterampilan Berpikir Kritis dalam Pembelajaran Matematika di SD. Artikel jurnal Forum Kependidikan, Volume 28, Nomor 2.

Majid, Abdul. 2014. Pembelajaran Tematik Terpadu. Bandung: Rosda

Slavin, Robert E. 2011. Psikologi Pendidikan jilid (1). Jakarta: Indeks

Sugiyono. 2009. Memahami Penelitian Kualitatif. Bandung:Alfabeta

Suparno, Paul. 2001. Teori Perkembangan Kognitif Jean Piaget. Yogyakarta: Kanisius

Takwin, Bagus. 2007. Mengajar anak berpikir kritis. (On line). Tersedia http://www.unisosdem.org/kli 
ping_detail.php?aid=6136\&c

oid=1\&caid=52.

$(24$

November 2015). 